\title{
JURNAL FASILKOM
}

(FAKULTAS ILMU KOMPUTER)

Vol. 7 Nomor 2 (2018) 255-258

ISSN : 2089-3353

\section{PERANCANGAN TEKNOLOGI VOICE OVER INTERNET PROTOCOL (VOIP) MEMANFAATKAN INFRASTRUKTUR JARINGAN LISTRIK}

\author{
Mitra Unik ${ }^{1)}$, Sunanto ${ }^{2)}$ \\ ${ }^{1}$ Fakultas Ilmu Komputer, Universitas Muhammadiyah Riau \\ email:mitraunik@umri.ac.id \\ ${ }^{2}$ Prodi Teknik Informatika, STMIK Amik Riau \\ email: Sunanto@stmik-amik-riau.ac.id
}

\begin{abstract}
Abstrak
Kolaborasi teknologi jaringan dan teknologi multimedia memicu munculnya sebuah ide baru dalam menyiapkan teknologi komunikasi audio (voice) yang lebih murah dari segi infrastruktur karena dapat memanfaatkan jaringan listrik sebagai media penghantar jaringan data. Gagasan utama di balik ide komunikasi listrik / Powerline Communication (PLC) yaitu memanfaatkan jaringan distribusi listrik sebagai distribusi data serta dengan konsep memanipulasi jaringan listrik menjadi jaringan komputer. Sehingga memungkinkan komunikasi antar perangkat komputer terjadi khususnya digunakan sebagai alternatif solusi guna mengakomodasi kebutuhan komunikasi data bagi bangunan yang terletak di daerah-daerah yang belum menyediakan jaringan telekomunikasi dasar.
\end{abstract}

Kata kunci: Power line communication, teknologi, Voice, distribusi

\section{PENDAHULUAN}

Pentingnya akses komunikasi merupakan subjek yang selalu diperdebatkan di seluruh negara, eksposisi perkembangan media informasi dan komunikasi menjadi indicator beberapa negara sebagai pembangunan masyarakat Society [08]. Manfaat jaringan komunikasi yang tersedia dan dengan latar belakang perkembangan tanpa henti memungkinkan masyarakat untuk berkomunikasi dengan satu dan lainnya. Namun, pada saat yang bersamaan khususnya di Indonesia, pemerintah belum mampu menyediakan jaringan telekomunikasi dasar di beberapa wilayah Indonesia Telsetnews[09]. Jaringan telekomunikasi dasar dapat berbasis kabel (kabel telepon) maupun sinyal.

Terwujudnya Gagasan Powerline Communication (PLC) yaitu memanfaatkan jaringan distribusi listrik sebagai distribusi data, menjadi alternatif solusi guna mengakomodasi kebutuhan komunikasi didaerah-daerah yang belum terjangkau jaringan komunikasi premium. Sistem PLC memungkinkan pembentukan akses baru jaringan komunikasi data melalui infrastruktur listrik yang sudah tersedia. PLC menjadi sangat kompetitif dengan layanan lainnya seperti ADSL, kabel jaringan atau komunikasi nirkabel. Melit, Nekhoul, Sekki, \& Kerroum [10].

Voice over Internet Protocol (VoIP) atau internet telepon merupakan salah satu bentuk komunikasi multimedia yang mampu mengirimkan trafik suara berbentuk paket digital secara real-time Purbo \& Raharja [11]. VoIP dianggap sebagai solusi teknologi komunikasi berbiaya rendah.

VoIP memanfaatkan infrastruktur jaringan (networking) sehingga teknologi ini memungkinkan komunikasi suara menggunakan jaringan berbasis IP (internet protocol) untuk dijalankan diatas infrastruktur jaringan paket network internet maupun intranet. VoIP mampu menciptakan komunikasi seperti layaknya menggunakan telepon biasa dan tidak dikenakan biaya telepon biasa untuk berkomunikasi dengan pengguna VoIP lainnya dimana saja dan kapan saja.

Jurnal Fasilkom Vol. 7 Nomor 2 (2018) 255-258 
Dengan adanya permasalahan akan kebutuhan penyebaran teknologi komunikasi diaerah-daerah yang belum tersentuh perusahaan jaringan telekomunikasi, dan didukung dengan adaya kedua teknologi "murah" ini yaitu jaringan komputer berbasis infrasturuktur listrik dan komunikasi telepon memanfaatkan jaringan (networking) berbasis Internet protocol, maka penulis akan berkonsentrasi pada subjek penelitian Perancangan Teknologi Komunikasi Voice Over Internet Protocol (VoIP) Memanfaatkan Infrastruktur Jaringan Listrik.

\section{METODE PENELITIAN}

Guna menyusun penelitian ini maka ada beberapa metode serta prosedur yang penulis terapkan dalam tahapan-tahap pengerjaan penelitian:

1. Studi Pendahuluan, yaitu sebagai kemungkinan diteruskannya pekerjaan meneliti dan mencari informasi yang diperlukan oleh peneliti agar masalah menjadi lebih jelas kedudukannya.

2. Pengembangan pengumpulan data, penelitian akan memperoleh tujuan yang diharapkan apabila didukung oleh data yang sahih dan reliable.

3. Analisis dan implementasi, menyusun hasil laporan dari tahap-tahapan sebelumnya dengan asumsi penelitian telah selesai dilaksanakan.

\section{MODEL PENELITIAN}

Jenis penelitian ini adalah Penelitian dan Pengembangan (Research and Development) dengan model ADDIE (Analysis, Design, Development, Implementation, and Evaluation). Model ADDIE diasaskan oleh Rosset pada tahun 1987, merupakan model reka bentuk yang berfungsi sebagai garis panduan ke arah proses yang menyediakan sarana untuk pengambilan keputusan untuk bagaimana sebuah penelitian tersebut dapat diselesaikan.

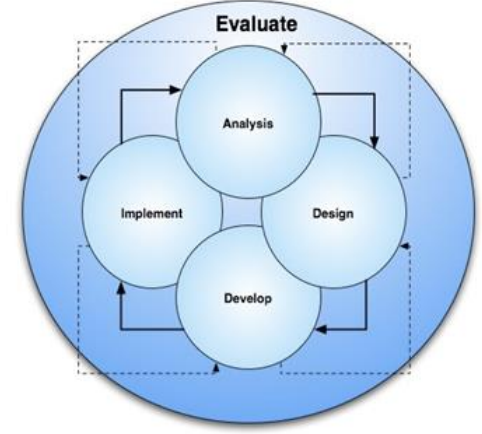

Gambar 1. Model ADDIE

\section{HASIL DAN PEMBAHASAN}

Jaringan VoIP menurut Yetti Yuniarti [06] Voice over internet protocol (VoIP) merupakan teknologi yang memanfaatkan internet protocol untuk menyediakan komunikasi voice (suara) secara elektronis dan real-time. Dengan kata lain VoIP adalah suatu teknologi komunikasi berbasis suara yang menggunakan media internet sebagai media transmisinya. Teknologi VoIP secara infrastruktur dapat mengantikan teknologi telepon PABX dan telepon kabel lainya, dengan teknologi Voip tidak perlu menambah infrastruktur baru untuk mendapatkan teknologi komunikasi berbasis suara. Karena Voip menggunakan infrastruktur yang sama dengan jaringan komputer. Maka dapat dilakukan komunikasi menggunakan suara, gambar dan video tanpa harus mengeluarkan biaya tambahan.

Power Line Communication (PLC) adalah system untuk membawa data pada konduktor yang juga digunakan untuk transmisi tenaga listrik. Sehingga jaringan listrik selain berfungsi sebagai sumber listrik juga menjadi media penghantar komunikasi. Daya listrik ditransmisikan melalui jalur transmisi tegangan tinggi, yang didistribusikan melalui tegangan menengah, dan digunakan di dalam gedung pada tegangan rendah. PLC dapat diterapkan pada setiap tahap. Kebanyakan teknologi PLC membatasi diri untuk satu set kabel (misalnya, kabel tempat), tetapi beberapa dapat silang antara dua tingkat (misalnya, baik jaringan distribusi dan kabel tempat). Biasanya trafo mencegah menyebarkan sinyal yang memungkinkan beberapa teknologi PLC dijembatani membentuk jaringan yang sangat besar. [07] 


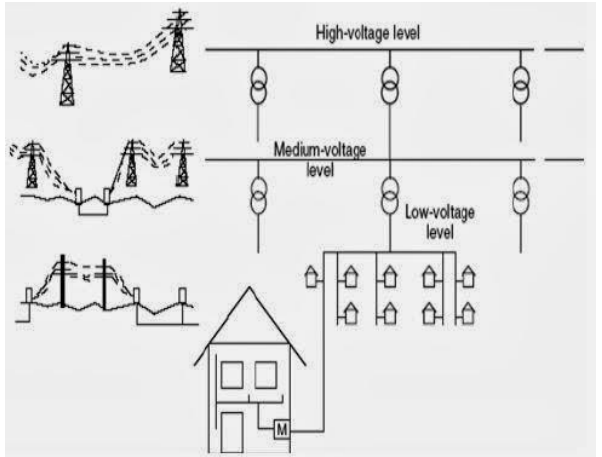

Gambar 2. Instalasi jaringan secara umum

Pada dasarnya penelitian ini menggabungkan dua buah skema dasar yaitu skema jaringan listrik dan skema topologi jaringan VOIP.

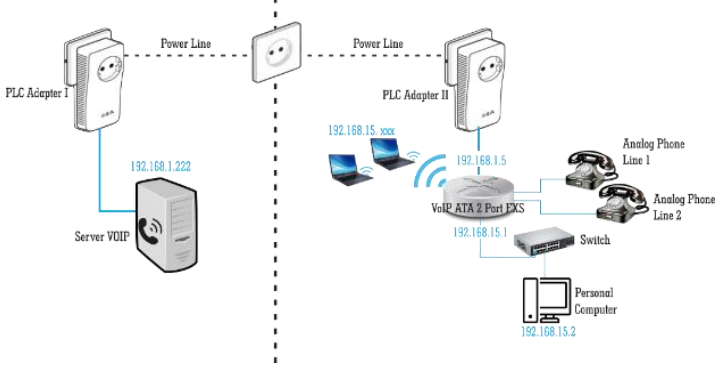

Gambar 3. Skema Penelitian

briker merupakan sistem operasi berbasis linux yang diperuntukan sebagai server VoIP, konfigurasi briker sangat mudah layaknya konfigurasi router wireless berbasis GUI (Grafical user Interface) briker yang digunakan adalah briker 1.4 "komodo dragon". Server briker VoIP memiliki IP address Class $\mathrm{C}$ yaitu 192.168.1.222, untuk melakukan konfigurasi operasional VoIP dapat mengetikan IP address pada url seperti terlihat pada gambar berikut ini.

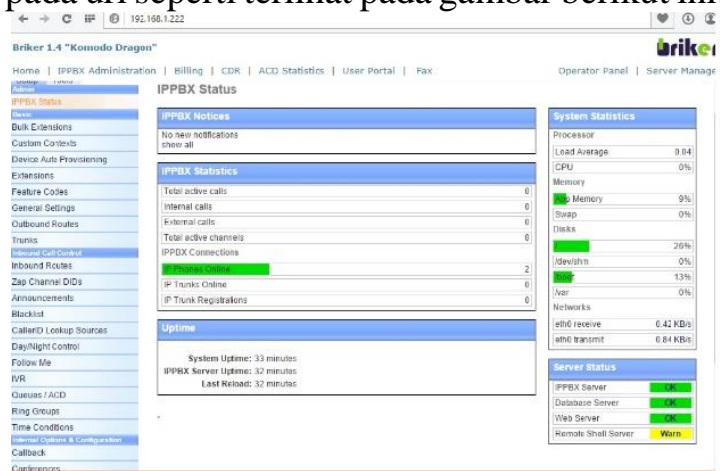

Gambar 4. WEBMIN Konfigurasi briker

Topologi yang digunakan adalah topologi yang telah dibahas pada bab 3 yaitu topologi yang memanfaatkan tiga media yaitu kabel data utp, kabel listrik tegangan rendah dan wireless. Komunikasi antara server dengan router voice wireless dilakukan menggunakan media powerline communication, sedangkan komunikasi telephone analog ke router voice menggunakan media kabel telephone. Pengaturan SIP media wireless digunakan untuk menghubungkan sip 100 dan media wireline digunakan untuk menghubungkan sip 104. Adapun topologi hardware pengujian dapat dilihat pada gambar berikut ini:

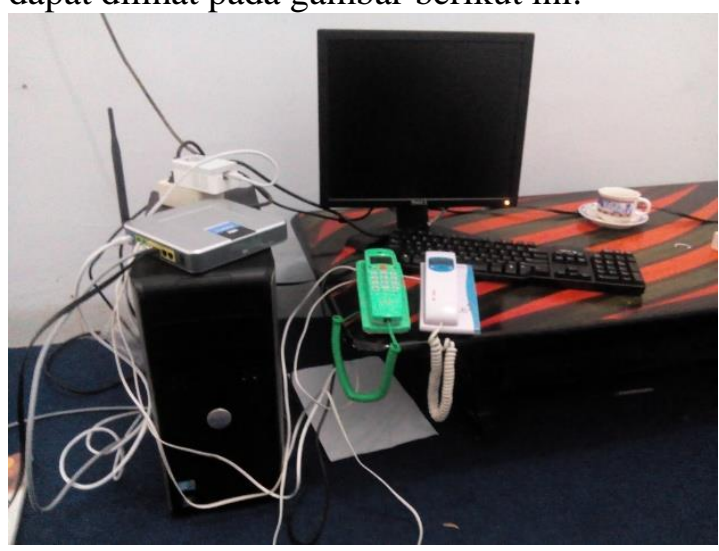

Gambar 5. Hasil dan pengujian komunikasi

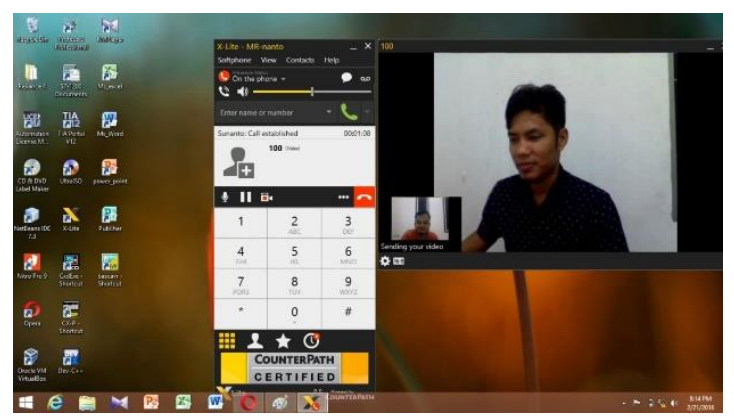

Gambar 6. Hasil pengujian komunikasi antara beberapa perangkat.

komunikasi computer dengan computer menggunakan software X-lite dapat dilakukan secara voice (suara), gambar dan video. Komunikasi yang dilakukan dengan dua arah yaitu komunikasi duplex menghasilkan suara dan video yang sangat baik, komunikasi berbasis computer to computer ini dapat dimanfaatkan untuk bertukar informasi berbasis video dan suara dari pengirim ke penerima pesan.

\section{SIMPULAN DAN SARAN}

Setelah dilakukan pengujian berdasarkan topologi VoIP yang terinstall maka dapat ditarika kesimpulan bahwa semua komunikasi dapat berjalan dengan baik. Komunikasi tersebut dapat dilakukan menggunakan media kabel listrik dengan memanfaatkan infrastruktur jaringan listrik dan wireless.

Jurnal Fasilkom Vol. 7 Nomor 2 (2018) 255-258 
Penggunaan power line communication (PLC) dapat di pasang pada infrastuktur yang tidak terjangkau oleh jaringan listrik, rumitnya kondisi medan apabila dilakukan pemasangan kabel data (UTP).

Saran yang dapat diberikan untuk penelitian yang akan dilakukan pada masa yang akan datang adalah, penggunaan jaringan listrik sebagai media penghantar jaringan terbatas pada alat yang sudah ada berupa sebuah power line communication (PLC). PLC yang dijual bebas di pasar memiliki keterbatasan dari segi jangkauan dan frekuensi yang dihasilkan. Agar penelitian ini dapat diimplementasikan lebih lanjut, maka perlu peralatan sejenis PLC yang dapat digunakan pada jaringan listrik transmisi dan jaringan listrik distribusi sehingga pemanfaatan infrastruktur jaringan listrik sebagai media komunikasi data dapat dimplementasikan diberbagai titik komunikasi

\section{TERIMA KASIH}

Penulis mengucapkan terima kasih kepada semua pihak yang telah memberi dukungan terhadap penelitian ini.

\section{DAFTAR PUSTAKA}

[1] Domiko Fadhi Jaya Patih, Helmy Fitriawan dan Yetti Yuniarti, Analisa Percancangan Server VoIP dengan opensource asterisk dan VPN (Virtual Private Network) sebagai pegaman jaringan antar client, Jurnal Informatika dan Teknik Elektro Terapan, ISSN 2303-0577, Volume 1 No 1 Januari 2012.

[2] Indra Warman dan Johari Maknum, Implementasi Voice Over Internet Protocol (VoIP) IP Phone Sebagai Media Pengganti Private Automatic Branch Exchage (PABX), Jurnal Momentum, ISSN 1693-752X, Volume 16 No.1 Februari 2014

[3] Gunarso Prasamuarso Kuntarto, Teknologi Power Line Communications (PLC) Berkaitan Dengan Aspek Teknik dan Ekonomi, Jurnal ULTIMATICS Volume 1 No. 1 Desember 2009

[4] Imam Suharjo, Analisis Penggunaan Jaringan Kabel Listrik Sebagai Media Komunikasi Data Internet, Jurnal Universitas Mercu Buana, ISSN 1693-6930

[5] Legiman Slamet, Membangun Jaringan Komunikasi Data Dengan Kabel Listrik Jala-Jala $50 \mathrm{~Hz}$ Sebagai Media Transmisinya Implementasi Powerline Communication Dalam Pendidikan, Jurnal Teknologi Informasi dan Pendidikan, ISSN 2086-4981, Volume 1 No.1 Maret 2010

[6] Yetti Yuniarti, Helmy Fitriawan dan Domiko Fadhi Jaya Patih, Analisa Percancangan Server VoIP dengan opensource asterisk dan VPN (Virtual Private Network) sebagai pegaman jaringan antar client, Jurnal Sains, Teknologi
Industri ISSN 1693-2390, Volume 1 No 1 Desember 2014.

[7] Wikipedia.org Powerline communication, akses tanggal 2 januari 2016

[8] Society, I. (2014). Benefits of an Open and Sustainable Internet. Global Internet Report, 3.

[9] Telsetnews. (2011). "'Indonesia Broadband"тм Solusi Penyebaran Akses Internet. Retrieved from http://telsetnews.com/29061/indonesiabroadband-solusi-penyebaran-akses-internet/

[10] Melit, M., Nekhoul, B., Sekki, D., \& Kerroum, K. (2012). Modeling of the transmission of power line communication signal through the power electric transformer. Annals of Telecommunications, 67(9-10), 447-454. http://doi.org/10.1007/s12243-011-0277-4

Purbo, O. W., \& Raharja, A. (2010). VoIP Cookbook: Building your own Telecommunication Infrastructure By. Internet Society Innovation Fund (ISIF) 